\title{
Some Accurately Measured Infrared Wavelengths for Calibration of Grating Spectrometers ${ }^{1}$
}

\author{
Earle K. Plyler, Norman M. Gailar, and Thomas A. Wiggins ${ }^{2}$
}

\begin{abstract}
The measured values of the wavelengths of 60 lines in the 1.1- to 2.3-micron spectral region are reported. The absorption lines of the bands of methane and water vapor were used in the calibration. The methods of measurement are discussed. Also discussed are the methods of superimposing the well-known emission lines of several sources on the absorption lines that were measured. The values obtained for some lines are compared with values reported by other workers.
\end{abstract}

\section{Introduction}

The infrared spectra of many substances have been recorded and measured, the results being used to calculate various molecular constants. The equipment used and the techniques of measurement have varied from one laboratory to another, and in many cases the values reported for the same quantity have differed. In addition, the modern infrared detectors have permitted the construction of grating spectrometers of much higher resolution than was previously possible. It now seems desirable to reevaluate the methods of measurement so that the greater resolving power available may be best utilized.

The simplest method of calibrating a spectrometer is to use one known wavelength and assume a sinusoidal dispersion. This method, of course, is the least accurate of those currently used. The next best method is to use two known wavelengths and assume linear dispersion between them. The closer together the two known wavelengths lie, the better the resulting measurements will be. This method is often extended to three or more known lines fitting a parabola or a cubic to them, thus establishing a scale to be used in that region. Experience in the radiometry laboratory of the Bureau indicates that this method often fails to yield wavelengths to the desired accuracy because of certain errors.

Errors in measurement obtained from a grating instrument are caused by several factors. Theoretically a grating should show a sinusoidal dispersion, and, to a first approximation, does. Thus, linear dispersion is suitable only to the extent that a straight line approximates a sine curve. The use of a quadratic or cubic expression more closely fits the sine relation. There are errors, however, that cause the dispersion to vary from the sinusoidal, and these cannot be compensated for by the use of a quadratic. There are systematic repeatable errors that can be attributed to irregularities in the gearing of the mechanism that drives the grating. These can, in effect, superimpose "ripples" on the sine wave. These effects can be minimized by using many standard wavelengths. Another type of error is a seeming random error that is not repeatable. Both types can be of considerable magnitude.

\footnotetext{
1 Supported by Office of Naval Research.

2 Present address: Pennsylvania State College, State-College, $\mathrm{Pa}$
}

The method of calibration used is to superimpose many well-known standard emission lines $(\mathrm{Hg}, \mathrm{Kr}$, $\mathrm{Xe}$, etc.) on the record of the substance being examined. Although this is standard procedure in photographic spectroscopy, it is not often used in infrared spectroscopy. The advantage of this superposition lies in the minimizing of the random errors. Lines measured this way seem to reproduce better on successive runs. When standards are available at small wavelength intervals, linear interpolation repeated several times averages out the random errors and gives results repeatable to 0.2 to $0.3 \mathrm{~A}$. When the standards are approximately $100 \mathrm{~A}$ or more apart, a dispersion curve is plotted and smoothed, and the results from several sets of readings are averaged. Measurements usually reproduce to better than $0.5 \mathrm{~A}$. Further refinements, which are discussed later, have made it possible to measure the lines reported in this paper to an accuracy better than $0.1 \mathrm{~A}$.

Inasmuch as many laboratories do not possess the equipment to place the required standard lines on their records, this paper presents the wavelengths of 60 accurately measured absorption lines in the 1.1 - to $2.3-\mu$ spectral range by utilizing the absorption of atmospheric water vapor and of natural gas, $\left(\mathrm{CH}_{4}\right)$, materials easily obtained. These 60 lines may be used to check or to establish the calibration of instruments, or they may be superimposed on records of absorption or emission.

\section{Experimental Details}

The absorption spectra of $\mathrm{CH}_{1}$ and $\mathrm{H}_{2} \mathrm{O}$ were obtained in five regions, higher orders of well-known emission lines being superimposed on the absorption. The source of the continuous energy for the absorption was the hot electrode of the discharge tubes, which provided the emission lines.

In order to have sufficient standard lines it was necessary to use two or more discharge tubes simultaneously. The arrangement of the sources is shown in figure 1, which shows two methods of introducing a third source. These methods are (1) using a spherical mirror, and (2) reflecting the light from the third source (marked neon) from a plane mirror that 


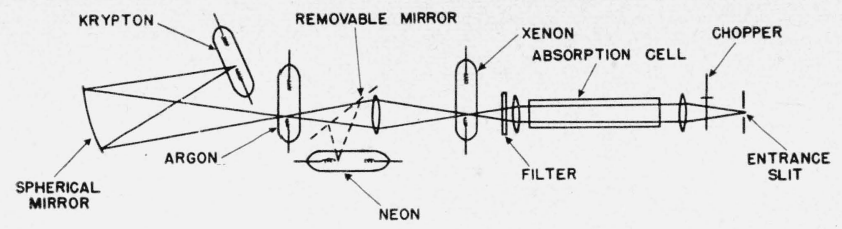

FIGURE 1. Arrangement of multiple sources and of absorption cell.

could be swung into position, momentarily directing this light onto the slit and intercepting one or both of the other sources.

The cell shown in figure 1 was a $60-\mathrm{cm}$ cell and was used for $\mathrm{CH}_{4}$. Previous tests having shown no measurable difference between the bands of pure $\mathrm{CH}_{4}$ and natural gas in this region, the cell was filled with natural gas.

The spectrometer has been described previously [1]. ${ }^{3} \quad$ It will suffice to state that it consists of a $1-\mathrm{m}$ off-axis paraboloidal mirror focusing the energy onto a 15,000 line/in. plane grating, and an ellipsoidal mirror to focus the diffracted energy onto a lead sulfide detector. The signal is amplified by a Wilson amplifier and recorded by a recording potentiometer. The chart speed and grating drive were adjusted to obtain dispersion of 12 to $20 \mathrm{~A} / \mathrm{in}$. This dispersion varied, depending on the spectral region and order number. The 1.1- and $1.3-\mu$ bands of water, for instance, were measured in the second order to obtain greater dispersion and to utilize emission lines that did not appear in the first-order regions of water.

Survey runs were made to determine which combinations of sources would be most useful in a given region. Sources were selected that provided emission lines reasonably close together, one of which fell near a well-defined absorption line.

It was observed in many cases that absorption lines were superimposed on emission lines, thereby producing distortion in the shape and position of the standards. In these cases a quarter-inch water cell was inserted in the optical path at the position marked "filter" in figure 1. This filter absorbed radiation of wavelength greater than $1.3 \mu$ and permitted the higher orders of standard lines, which are of shorter wavelength, to be recorded undisturbed. In a similar manner an emission line of order greater than the first could be removed by a different filter, so that the absorption line could be accurately recorded.

The output of the amplifier was attenuated when an intense emission line was being recorded. This gave the pen ample time to record the line and permitted more accurate location of the line center. In one case the slit was widened and the amplifier gain increased in order to utilize weak emission lines, the pen being kept on scale by attenuation. Near an emission line the water cell was placed in position and the attenuation removed, allowing the line to be recorded with sufficient intensity to be easily measurable.

Figures in brackets indicate the literature references at the end of this paper.

\section{Measurement}

The method of measurement consisted primarily of using linear dispersion between two closely spaced known lines. The absorption lines measured were those that showed no structure under the highest dispersion available. In general, lines to be measured were chosen as near a standard line as possible, as it was found on successive runs that the measured wavelengths of these lines reproduced best.

At times, it was impossible to find two standards near enough. In these cases two absorption lines flanking an emission standard would be identified from other papers $[2,3]$, and the wavelengths from these papers would be used to calculate a dispersion factor. This factor would then be used in conjunction with the emission line. As the absorption lines measured in these cases were all very near the emission lines, relatively large variances in the dispersion factors made only small differences in the measured valued of the wavelengths of the absorption lines. The relative accuracy of this method was established by measuring several lines by both methods, the results always differing by less than $0.1 \mathrm{~A}$.

In order to minimize the effects of the random errors, six runs were made of every line measured. As there was often a small difference in the measured value of a line when the instrument ran toward higher wavelengths in comparison with the value when run toward shorter wavelengths, half of the runs were taken in each direction.

All but two of the standard lines have been measured interferometrically [4]. These two lines have been reported to $0.01 \mathrm{~A}$ from intercomparison methods.

\section{Results}

Tables 1 to 5 present the measured values of the 60 lines. In addition, the tables include the wave numbers reduced to vacuum, the nearest emission lines used as standards and, where possible, the results of measurements of other workers $[2,3,5,6,7]$ given for comparison. The lines felt to be the most accurate are marked with a superscript "a". These lines all fell very near a standard line and, in addition, had an average deviation from the mean of $\pm 0.1 \mathrm{~A}$ or less. The wave numbers were found by inverting Kayser's tables [8] with Babcock's [9] correction for the change of index of refraction of air in the infrared.

In the case of methane, the absorption spectrum was taken at two different pressures, $18 \mathrm{~cm}$ of $\mathrm{Hg}$ to sharpen the strong lines, $76 \mathrm{~cm}$ of $\mathrm{Hg}$ to show the weaker outer lines. It is recommended that these pressures be employed when the observed wavelengths for methane are to be used as standards.

Figures 2, 3, and 5 are actual records obtained of the absorption spectra of water at $1.1,1.3$, and $1.8 \mu$, respectively. Figures 4 and 6 are similar records of $\mathrm{CH}_{4}$ at 1.7 and $2.2 \mu$, respectively. To aid identification, the wavelengths of some lines not measured 
TABLE 1. Results of measurement in the 1.1- $\mu$ band of $\mathrm{H}_{2} \mathrm{O}$

\begin{tabular}{|c|c|c|c|c|}
\hline \multicolumn{4}{|c|}{ Water-vapor absorption } & \multirow[b]{2}{*}{$\begin{array}{l}\text { Standardizing wave- } \\
\text { length employed } \\
\text { (grating order) }\end{array}$} \\
\hline $\begin{array}{l}\text { Observed wave- } \\
\text { length }\end{array}$ & $\begin{array}{l}\text { Vacuum } \\
\text { wave } \\
\text { number }\end{array}$ & $\begin{array}{c}\text { Babcock } \\
\text { and Moore } \\
\text { wavelengths } \\
{[5]}\end{array}$ & $\begin{array}{c}\text { Kiess } \\
\text { wave- } \\
\text { lengths } \\
{[7]}\end{array}$ & \\
\hline $\begin{array}{c}A \\
\text { s } 11180.60 \pm .06 \\
\text { a } 11251.06 \pm .08 \\
11294.4 \\
11405.7 \\
11463.7\end{array}$ & $\begin{array}{c}c m^{-1} \\
8941.55 \\
8885.59 \\
8851.53 \\
8765.11 \\
8720.80\end{array}$ & \begin{tabular}{c}
$A$ \\
11180.98 \\
\hdashline 11294.47 \\
11405.95 \\
\end{tabular} & $\begin{array}{c}A \\
11180.75 \\
11251.15 \\
11294.42 \\
11405.83 \\
11463.69\end{array}$ & \begin{tabular}{lcc}
\multicolumn{3}{c}{$A$} \\
$\mathrm{Ne}$ & b 1 & 11177.51 \\
$\mathrm{~A}$ & $3 / 2$ & 11255.80 \\
$\mathrm{Ne}$ & $3 / 2$ & 11303.66 \\
$\mathrm{Kr}$ & $3 / 2$ & 11402.32 \\
$\mathrm{~A}$ & $3 / 2$ & 11452.66
\end{tabular} \\
\hline
\end{tabular}

a Indicate lines considered to be most accurate.

b The fraction represents the factor for correcting for order number. Thus $3 / 2$ indicates the measurement of the standard line in the third order and of the absorption line in the second order. The division of the order number into the apparent wavelength at the right gives the actual wavelength of the standard line.

TABLE 2. Results of measurement in the 1.33- to 1.48- $\mu$ band of $\mathrm{H}_{2} \mathrm{O}$

Run in second order

\begin{tabular}{|c|c|c|c|c|c|}
\hline \multicolumn{3}{|c|}{ Water-vapor absorption } & \multirow{2}{*}{\multicolumn{3}{|c|}{$\begin{array}{l}\text { Standardizing wave } \\
\text { length employed } \\
\text { (grating order) }\end{array}$}} \\
\hline $\begin{array}{l}\text { Observed wave- } \\
\text { length }\end{array}$ & $\begin{array}{l}\text { Vacuum wave } \\
\text { number }\end{array}$ & $\begin{array}{l}\text { Nelson wave- } \\
\text { lengths [3] }\end{array}$ & & & \\
\hline $\begin{array}{c}A \\
13437.0 \\
\mathrm{~s} 13571.49 \pm .05 \\
13638.1 \\
13665.2 \\
13740.8\end{array}$ & $\begin{array}{c}c m^{-1} \\
7440.12 \\
7366.37 \\
7330.40 \\
7315.86 \\
7275.59\end{array}$ & $\begin{array}{c}A \\
13436.9 \\
13571.2 \\
13638.4 \\
13665.5 \\
13740.5\end{array}$ & $\begin{array}{l}\mathrm{Ne} \\
\mathrm{Xe} \\
\mathrm{Hg} \\
\mathrm{Hg} \\
\mathrm{Xe}\end{array}$ & $\begin{array}{l}\text { b } 2 \\
3 / 2 \\
5 / 2 \\
5 / 2 \\
3 / 2\end{array}$ & $\begin{array}{l}13434.08 \\
13568.17 \\
13651.84 \\
13651.84 \\
13743.98\end{array}$ \\
\hline $\begin{array}{l}\text { \& } 13835.07 \pm .07 \\
\text { a } 13935.12 \pm .06 \\
14069.0 \\
\text { a } 14172.5 \\
\text { a } 14269.16 \pm .07\end{array}$ & $\begin{array}{l}7226.04 \\
77174.16 \\
7105.89 \\
7054.01 \\
7006.24\end{array}$ & $\begin{array}{l}13835.1 \\
13935.4 \\
14069.0 \\
14172.2 \\
14269.4\end{array}$ & $\begin{array}{l}\mathrm{A} \\
\mathrm{A} \\
\mathrm{Ne} \\
\mathrm{Hg} \\
\mathrm{Hg}\end{array}$ & $\begin{array}{l}3 / 2 \\
2 \\
2 \\
2 \\
7 / 2\end{array}$ & $\begin{array}{l}13836.75 \\
13930.86 \\
14064.83 \\
14163.88 \\
14272.41\end{array}$ \\
\hline $\begin{array}{l}14357.2 \\
1425.3 \\
14502.0 \\
14599.1 \\
14628.4\end{array}$ & $\begin{array}{l}6963.25 \\
6930.38 \\
6893.71 \\
6847.86 \\
6834.15\end{array}$ & $\begin{array}{l}14357.1 \\
14425.6 \\
14502.02 \\
14599.7 \\
14628.5\end{array}$ & $\begin{array}{l}\mathrm{Ne} \\
\mathrm{Hg} \\
\mathrm{Ne} \\
\mathrm{Hg} \\
\mathrm{Hg}\end{array}$ & $\begin{array}{l}2 \\
5 / 2 \\
2 \\
4 \\
4\end{array}$ & $\begin{array}{l}14347.88 \\
14424.00 \\
14490.33 \\
14619.35 \\
14619.35\end{array}$ \\
\hline $\begin{array}{l}\text { \& } 14706.69 \pm .05 \\
\text { \& } 14766.72 \pm .06\end{array}$ & $\begin{array}{l}6797.75 \\
6770.14\end{array}$ & $\begin{array}{l}14707.3 \\
14767.0\end{array}$ & $\underset{\mathrm{A}}{\mathrm{Ne}}$ & $\begin{array}{l}5 / 2 \\
2\end{array}$ & $\begin{array}{l}\text { 14704. } 74 \\
14767.96\end{array}$ \\
\hline
\end{tabular}

a Indicates lines considered to be most accurate.

b The fraction represents the factor for correcting for order number. Thus $3 / 2$ indicates the measurement of the standard line in the third order and of the absorption line in the second order. The division of the order number into the
apparent wavelength at the right gives the actual wavelength of the standard line

TABLE 3. Results of measurements in the 1.7- $\mu$ band of $\mathrm{CH}_{4}$

\begin{tabular}{|c|c|c|c|c|c|c|}
\hline \multicolumn{4}{|c|}{ Methane absorption } & \multirow{2}{*}{\multicolumn{3}{|c|}{$\begin{array}{l}\text { Standardizing wave- } \\
\text { length employed } \\
\text { (grating order) }\end{array}$}} \\
\hline $\begin{array}{l}\text { Observed wave } \\
\text { length }\end{array}$ & $\begin{array}{l}\text { Vacuum } \\
\text { wave } \\
\text { number }\end{array}$ & $\begin{array}{c}\text { Nelson, } \\
\text { Plyer, and } \\
\text { Benedict } \\
\text { wave- } \\
\text { lengths } \\
{[2]}\end{array}$ & $\begin{array}{c}\text { McMath, } \\
\text { Mohler, } \\
\text { and } \\
\text { Goldberg } \\
\text { wave } \\
\text { lengths } \\
\text { [6] }\end{array}$ & & & \\
\hline $\begin{array}{r}A \\
16233.9\end{array}$ & $\begin{array}{l}c m-1 \\
6158.27\end{array}$ & $\begin{array}{c}A \\
16233.7\end{array}$ & $A$ & $\mathrm{Kr}$ & 2 & $\stackrel{A}{A}$ \\
\hline 16349.9 & 6114. 53 & 16349. 4 & 16349.6 & $\mathrm{Kr}$ & 2 & 16380.11 \\
\hline 16398.9 & 6096. 23 & 16398.7 & 16398.9 & $\mathrm{Kr}$ & 2 & 16380.11 \\
\hline $\begin{array}{l}16451.0 \\
0\end{array}$ & 6076. 99 & 16450.6 & 16450.8 & $\mathrm{Xe}$ & 2 & 16463.27 \\
\hline 16532.8 & 6046. 93 & 15532.5 & 16532.9 & $\mathrm{Kr}$ & 2 & 16526.48 \\
\hline 16561.2 & 6036.55 & 16560.0 & 16561.1 & $\mathrm{Xe}$ & 2 & 16560.23 \\
\hline 16589.7 & $\begin{array}{l}6026.19 \\
6020\end{array}$ & 16589.0 & 16589.8 & $\mathrm{Kr}$ & 2 & 16596.22 \\
\hline 16739.9 & 5972.12 & 16739.5 & 16740.0 & $\mathrm{Ne}$ & & 16755. 21 \\
\hline 16835.6 & 5938. 17 & 16835. 2 & 16835.6 & A & & 16849. 29 \\
\hline 16868.2 & 5926.70 & 16868.0 & 16868.4 & $\mathrm{~A}$ & 2 & 16849.29 \\
\hline \& $17023.07 \pm .04$ & 5872.78 & 17022.7 & -....... & $\mathrm{Kr}$ & 2 & 17017.74 \\
\hline 17165.7 & 5823. 99 & 17164.7 & -....... & $\mathrm{Ne}$ & & 17182. 52 \\
\hline 17315. 3 & 5773. 66 & 17315.1 & - n-... & $\mathrm{Hg}$ & 3 & 17308.80 \\
\hline 17363.7 & 5757.57 & & -......- & & & 17371.99 \\
\hline
\end{tabular}

a Indicates line considered to be most accurate.
TABLE 4. Results of measurements in the 1.7\%-to 1.98- $\mu$ band of water

\begin{tabular}{|c|c|c|c|c|c|}
\hline \multicolumn{3}{|c|}{ Water-vapor absorption } & \multirow{2}{*}{\multicolumn{3}{|c|}{$\begin{array}{l}\text { Standardizing wave- } \\
\text { length employed } \\
\text { (grating order) }\end{array}$}} \\
\hline $\begin{array}{c}\text { Observed wave- } \\
\text { length }\end{array}$ & $\begin{array}{c}\text { Vacuum wave } \\
\text { number }\end{array}$ & $\begin{array}{l}\text { Nelson wave- } \\
\text { lengths [3] }\end{array}$ & & & \\
\hline $\begin{array}{c}\quad A \\
\text { 17843. } 5 \\
\mathrm{a} 17965.71 \pm .10 \\
\text { 18085. } 2 \\
\text { 18216.5 } \\
\text { 18296. } 9\end{array}$ & $\begin{array}{l}c m-1 \\
5602.75 \\
5564.64 \\
5527.87 \\
5488.03 \\
5463.89\end{array}$ & $\begin{array}{c}A \\
17843.3 \\
17965.0 \\
18085.2 \\
18216.2 \\
18296.7\end{array}$ & $\begin{array}{l}\mathrm{Ne} \\
\mathrm{Xe} \\
\mathrm{Ne} \\
\mathrm{Ne} \\
\mathrm{Ne}\end{array}$ & $\begin{array}{l}3 \\
2 \\
3 \\
3 \\
3\end{array}$ & $\begin{array}{c}A \\
17834.50 \\
17975.14 \\
18089.99 \\
18223.01 \\
18288.49\end{array}$ \\
\hline $\begin{array}{l}\text { 18415. } 7 \\
18482.0 \\
18637.2 \\
18917.3 \\
\mathrm{a} 19156.58 \pm .10\end{array}$ & $\begin{array}{l}5428.69 \\
5409.19 \\
5364.15 \\
5284.73 \\
5218.71\end{array}$ & $\begin{array}{l}18415.6 \\
18481.7 \\
18637.2 \\
18917.1 \\
19156.4\end{array}$ & $\begin{array}{l}\mathrm{Ne} \\
\mathrm{Ne} \\
\mathrm{Ne} \\
\mathrm{Ne} \\
\mathrm{Ne}\end{array}$ & $\begin{array}{l}3 \\
3 \\
3 \\
3 \\
3\end{array}$ & $\begin{array}{l}18429.19 \\
18490.78 \\
18651.84 \\
18914.37 \\
19148.97\end{array}$ \\
\hline $\begin{array}{l}19202.3 \\
19528.4\end{array}$ & $\begin{array}{l}5206.27 \\
5119.34\end{array}$ & $\begin{array}{l}19202.2 \\
19528.0\end{array}$ & $\begin{array}{l}\mathrm{Ne} \\
\mathrm{Ne}\end{array}$ & $\begin{array}{l}3 \\
3\end{array}$ & $\begin{array}{l}19206.74 \\
19519.58\end{array}$ \\
\hline
\end{tabular}

a Indicates lines considered to be most accurate.

TABLE 5. Results of measurement in the 2.2- $\mu$ bands of $\mathrm{CH}_{4}$

\begin{tabular}{|c|c|c|c|c|}
\hline \multicolumn{2}{|c|}{ Methane absorption } & \multirow{2}{*}{\multicolumn{3}{|c|}{$\begin{array}{l}\text { Standardizing wave- } \\
\text { length employed } \\
\text { (grating order) }\end{array}$}} \\
\hline $\begin{array}{c}\text { Observed } \\
\text { wavelength }\end{array}$ & $\begin{array}{c}\text { Vacuum } \\
\text { wave number }\end{array}$ & & & \\
\hline$A$ & $c m-1$ & & & $A$ \\
\hline 21543.3 & 4640.56 & $\mathrm{Ne}$ & 3 & 21521.82 \\
\hline 21834.1 & 4578.75 & $\mathrm{Hg}$ & 4 & 21842. 94 \\
\hline 22199.8 & 4503.32 & $\mathrm{Xe}$ & 2 & 22217.05 \\
\hline 22330.8 & 4476.91 & $\mathrm{Ne}$ & 3 & 22316. 70 \\
\hline 22449.9 & 4454.12 & $\mathrm{Ne}$ & 3 & 22466.61 \\
\hline 22490.9 & 4445.02 & $\mathrm{Ne}$ & 3 & 22466.61 \\
\hline 22610.9 & 4421.43 & $\mathrm{Ne}$ & 3 & 22607.32 \\
\hline 22775.6 & 4389.47 & $\mathrm{Kr}$ & 3 & 22762.24 \\
\hline 23068.8 & 4333.68 & $\mathrm{Kr}$ & 3 & 23055.74 \\
\hline 23394.0 & 4273.43 & $\mathrm{Ne}$ & 4 & 23409.95 \\
\hline 23512.8 & 4251.84 & $\mathrm{Ne}$ & & 23527.58 \\
\hline 23577.2 & 4240.20 & $\mathrm{Kr}$ & 3 & 23564.46 \\
\hline
\end{tabular}

for this paper are reported. The present values are underlined. Table 1 shows a very close agreement between these values and those of Kiess [7]. As a result of this good agreement, figure 2 includes the values reported by Kiess for many lines. They are believed to be accurate to $\pm 0.1 \mathrm{~A}$.

Two bands of $\mathrm{CO}$ have been measured and reported separately [10]. The results therein reported supplement the wavelengths reported here, so that standards are available over practically the whole spectrum from 1.1 to $2.5 \mu$.

These measurements constitute the first part of a larger program. It is intended to extend these measurements to cover the entire spectral range from 1 to $6 \mu$.

The authors thank Carl C. Kiess, who kindly permitted the use of his measurements in the 1.1- $\mu$ water band. Publication of his complete results, obtained at the Bureau, is pending.

\section{References}

[1] E. K. Plyler and N. M. Gailar, J. Research NBS 47, 248 (1951) RP2249.

[2] R. C. Nelson, E. K. Plyler, and W. S. Benedict, J. Research NBS 41, 615 (1948) RP1944. 
[3] R. C. Nelson, The Absorption of water vapor in the region 1.33 to 1.48 and 1.77 to 1.98 microns, Summary Report IV, Contract NObs 28373 (Northwestern Univ., May 23, 1949).

[4] W. F. Meggers, and C. J. Humphreys, J. Research NBS 13, 293 (1934) RP710; C. J. Humphreys and W. F. Meggers, BS J. Research 10, 139 (1933) RP521; K. Burns, K. B. Adams, and J. Longwell, J. Opt. Soc. Am. 40, 339 (1950).
[5] H. D. Babcock and C. E. Moore, The solar spectrum $\lambda 6600$ to $\lambda 13495$, Carnegie Institution of Washington Publication \#579 (1947).

[6] R. R. McMath, O. C. Mohler, and L. Goldberg, Astrophys. J. 109, 17 (1949).

[7] C. C. Kiess, publication pending.

[8] H. Kayser, Tabelle der Schwingungszahlen, Revised ed. (J. W. Edwards, Ann Arbor, Mich., 1944).

[9] H. D. Babcock, Phys. Rev. 46, 382 (1934).

[10] Earle K. Plyler, W. S. Benedict, and Shirleigh Silverman, J. Chem. Phys. 20, 175 (1952).

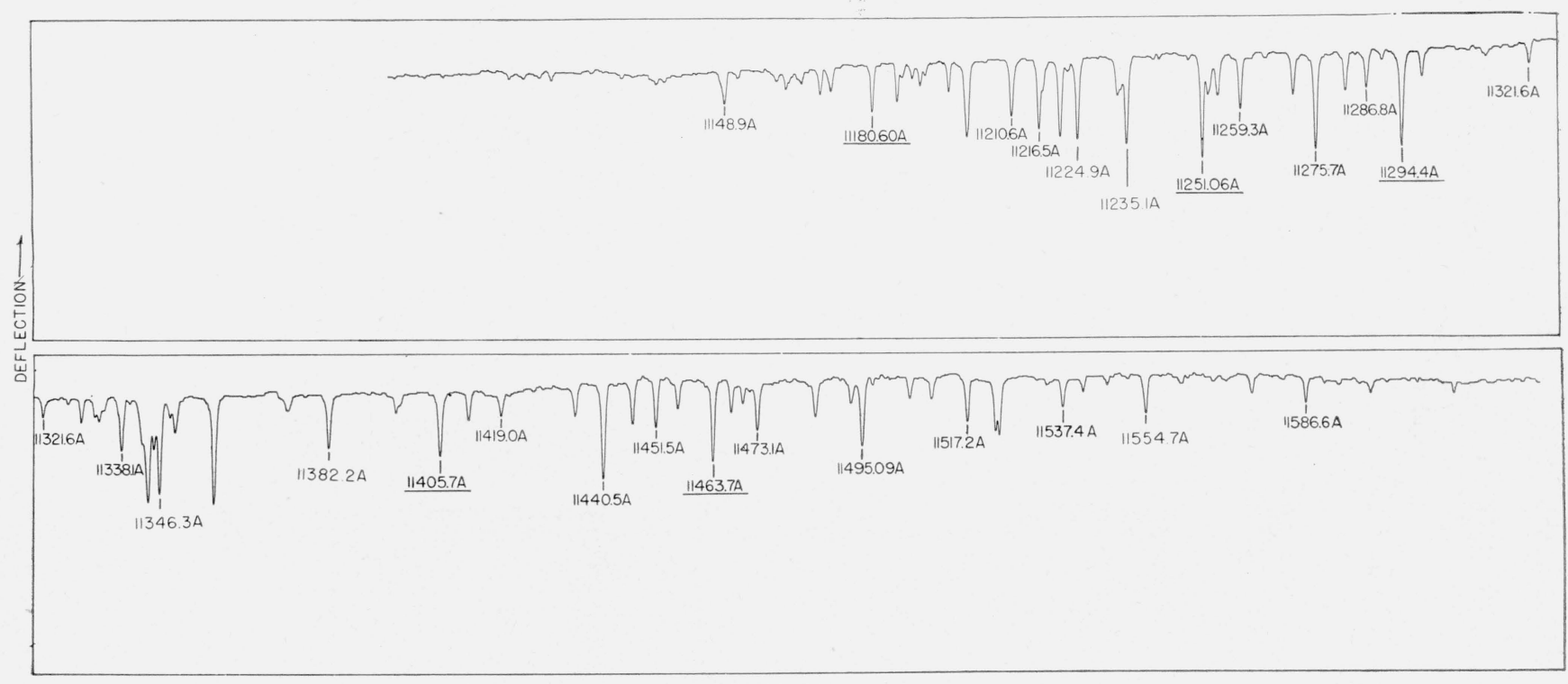

WAVELENGTH $\longrightarrow$

Figure 2. Absorption of atmospheric water at $1.1 \mu$.

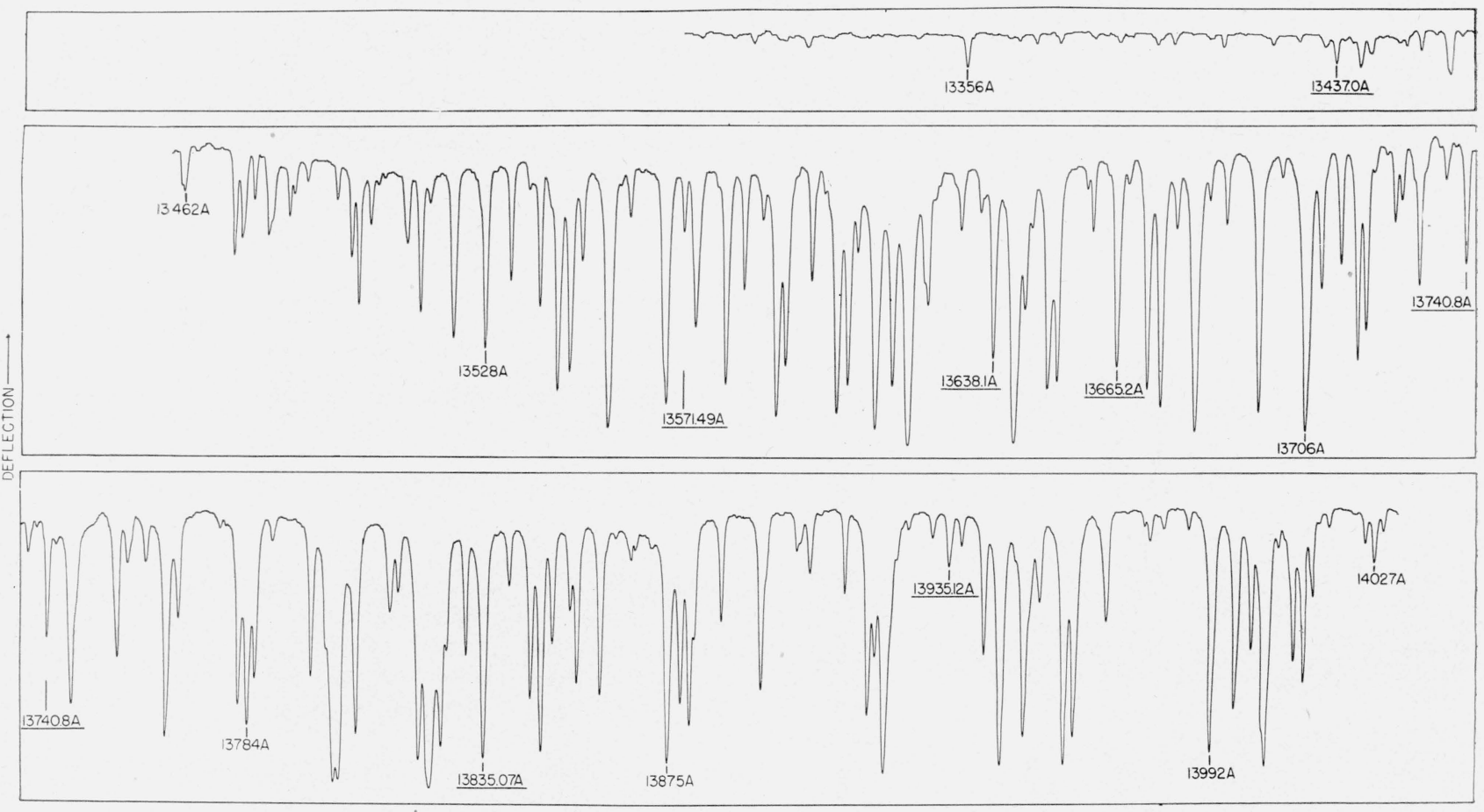

WAVELENGTH $\longrightarrow$

Figure 3. Absorption of atmospheric water at $1.3 \mu$. 

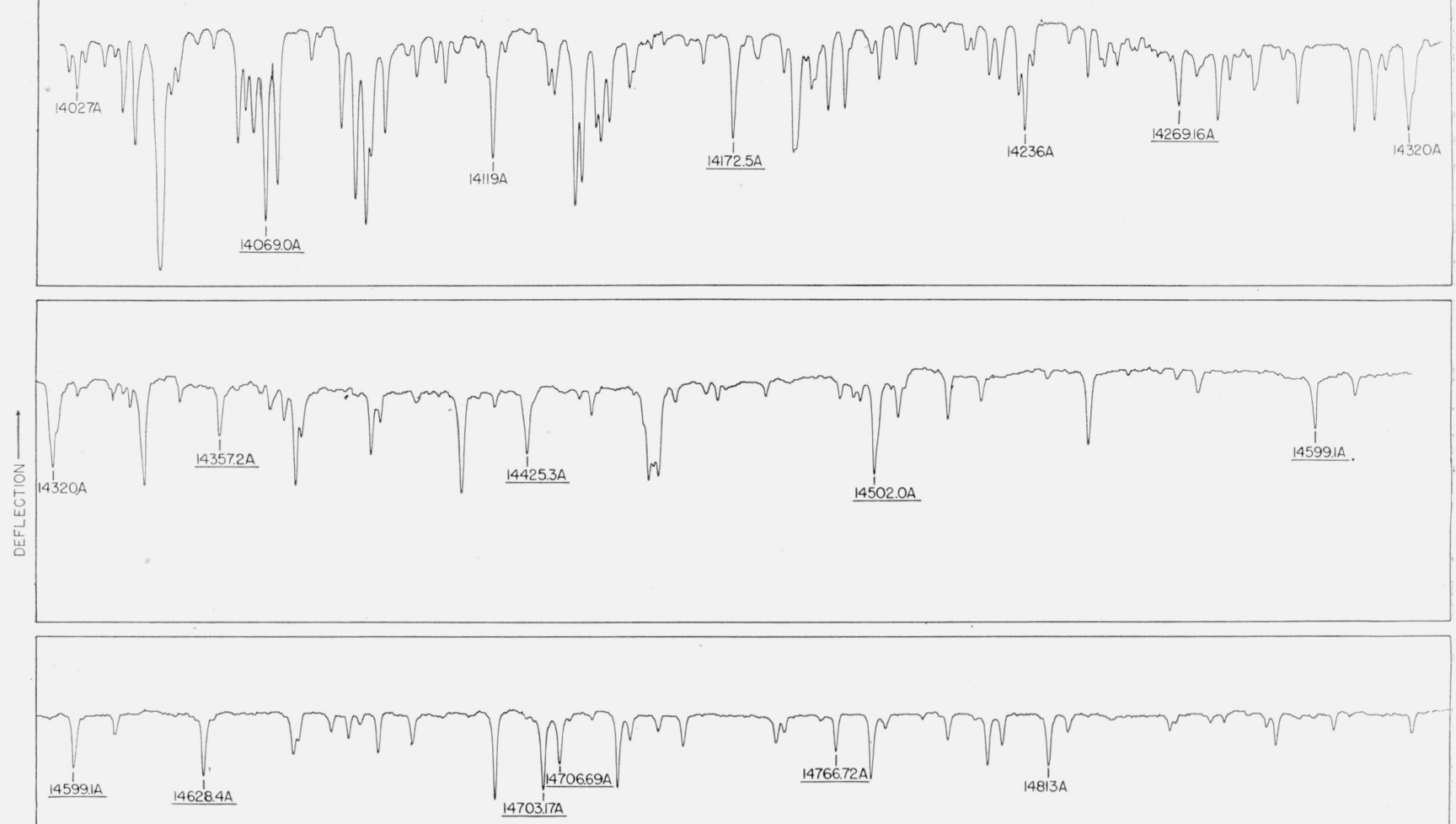

WAVELENGTH

Figure 3.-Continued.

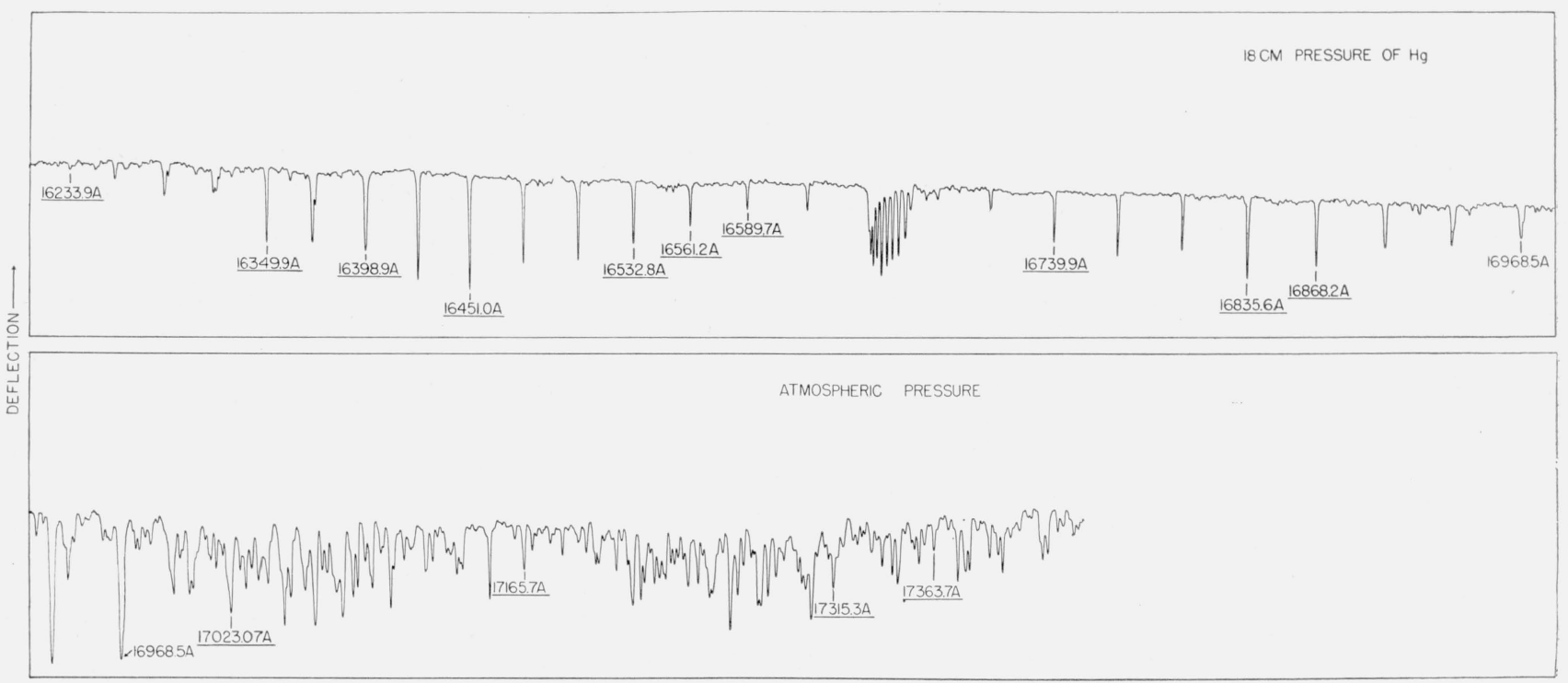

WAVELENGTH $\longrightarrow$

FIGURE 4. Absorption of $\mathrm{CH}_{4}$ at $1.7 \mu$. 

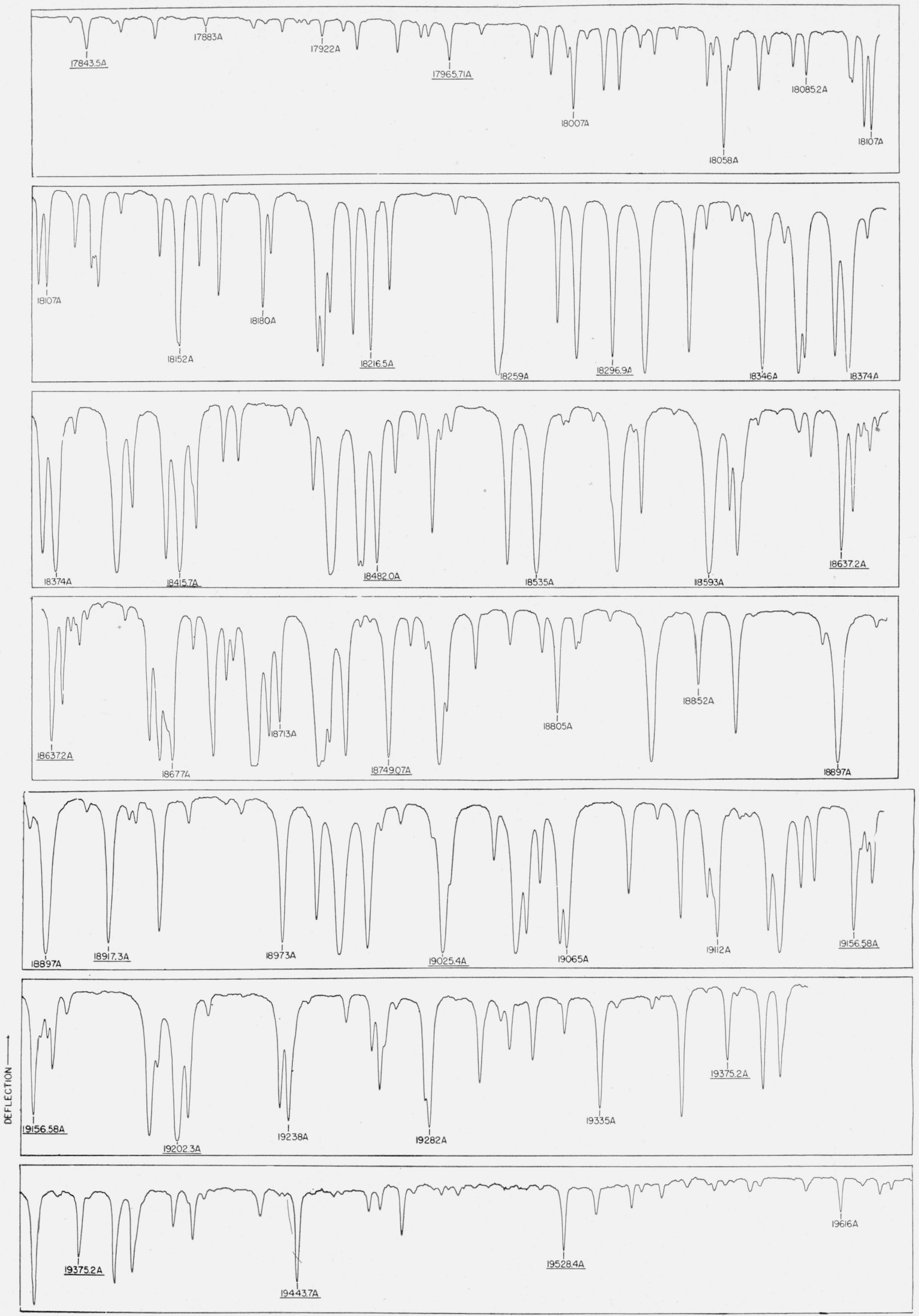

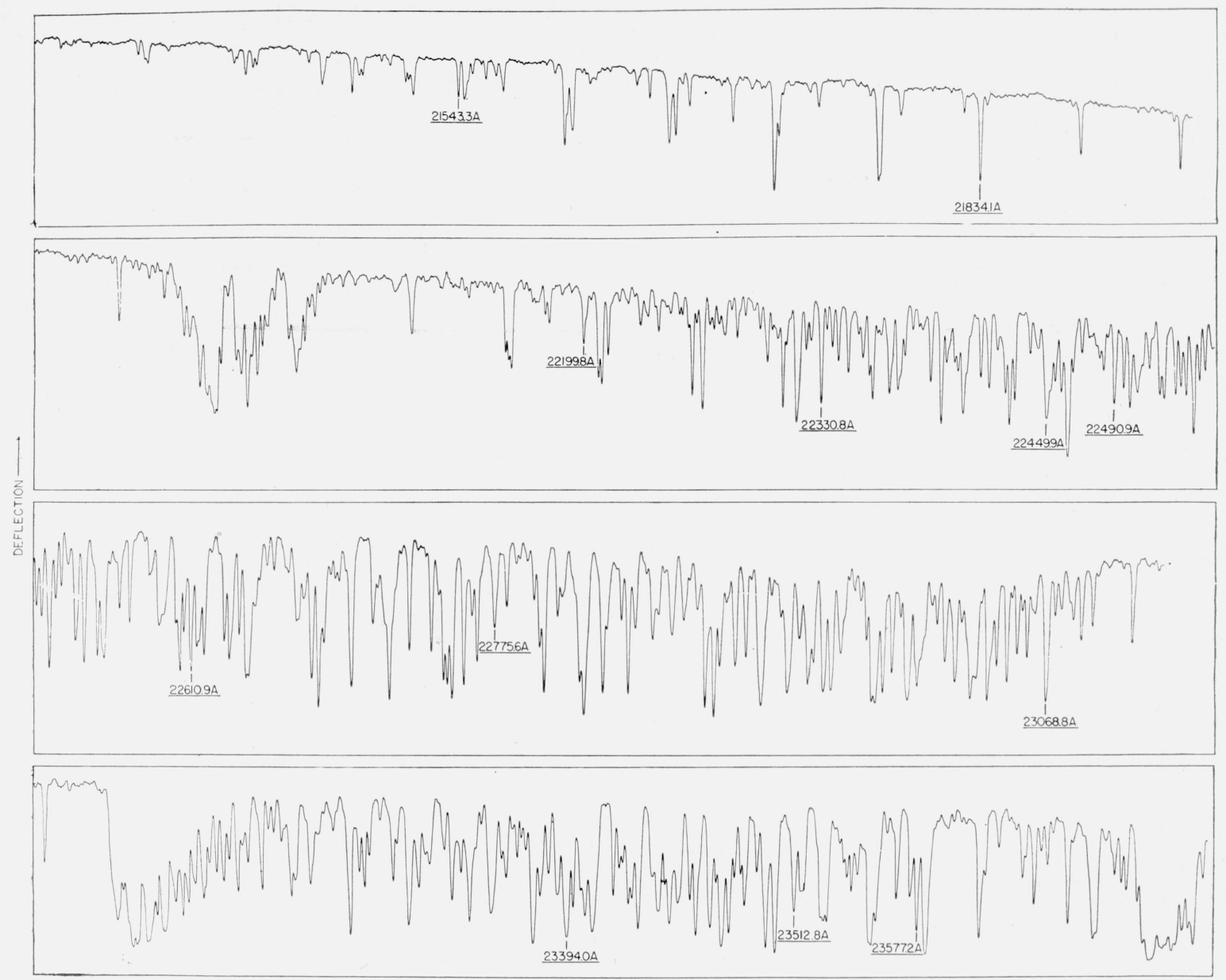

WAVELENGTH $\longrightarrow$

Figure 6. Absorption of $\mathrm{CH}_{4}$ at $2.2 \mu$.

The pressure was atmospheric.

Washington, November 23, 1951. 